\title{
Cutis marmorata as a manifestation of congenital hypothyroidism
}

\author{
Ayesha Ahmad ${ }^{1}$ \\ Sri Lanka Journal of Child Health 2013; 42: 222-223
}

(Key words: Cutis marmorata telangiectatica congenita; CMTC; congenital hypothyroidism)

\section{Case Report}

A 9 month old girl, of a non-consanguineous marriage, was born at term with a birth weight of $2.9 \mathrm{~kg}$. Her family history and antenatal course were non-contributory. The presentation was with a reticular rash all over the body with ulcerations of 2 months duration. The rash which was violaceous, started from the legs and spread to the entire body (Figure 1)

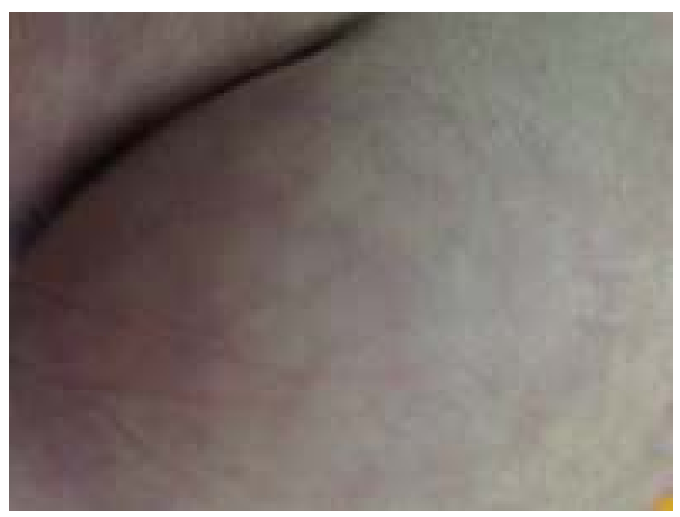

Figure 1: violaceous rash

It was associated with ulceration and scarring. The milestones were delayed and she showed head lag, absence of object holding, transfer of objects and mouthing. Her language included monosyllables only. Her complete haemogram, kidney and liver functions, ultrasonogram (USG) of the abdomen and computed tomography (CT) of the head, were within normal limits, but thyroid profile showed marked derangement (serum TSH: 152mIU/L, Free T4: $1.99 \mathrm{ng} / \mathrm{dl})$. She had no other features suggestive of hypothyroidism such as wide open anterior fontanelle, macroglossia, umbilical hernia, hypotonia or cold dry skin. USG of the neck and technetium scan were done but failed to localize any thyroid tissue thereby confirming thyroid dysgenesis as the cause of hypothyroidism.

A clinical diagnosis of Cutis Marmorata Telangiectatica Congenita (CMTC) was made on the basis of the characteristic clinical picture.

\author{
${ }^{1}$ Assistant Professor in Paediatrics, Aligarh Muslim \\ University, India
}

(Received on 9 February 2013: Accepted after revision on 22 March 2013)
Histological examination of the rash was not done based on the fact that the findings are non-specific and non-diagnostic in CMTC and the diagnosis is mainly clinical. She was treated as a case of cutis marmorata with congenital hypothyroidism, an association which has rarely been described ${ }^{1,2}$.

\section{Discussion}

In the year 2000, Enjolras and Mulliken related this disease to another disorder of pigmentation called Phacomatosis Pigmentovascularis (PPV) which is a disorder of skin characterised by normal pigmentation due to vascular and melanocytic abnormality $^{3}$. It was subclassified into 4 types based on the classification by Hasegawa and Vasuhara. CMTC was later classified as type 5 PPV as it has both melanocytic and vascular components which have been proposed to be due to a genetic concept called the "Twin Spotting Phenomena" - double heterozygosity with a recessive vascular mutation on one chromosome and the pigmentary mutation on the homologous chromosome ${ }^{4}$.

Lesions are observed at or shortly after birth in most of the patients; however in some reports patient did not develop any lesion until 3 months or even till 2 years after birth. CMTC is often associated with other abnormalities which include musculoskeletal (hemihypertrophy, hypoplasia, cutaneous atrophy, macrocephaly, scoliosis), ocular (glaucoma, retinal detachment, pigmentation) and central nervous system manifestations (hydrocephalus, mental retardation). Uncommon associations include patent ductus arteriosus, congenital hypothyroidism, mild growth deficiency, syndactyly, high arched palate, micrognathia, multicystic renal disease and neonatal lupus ${ }^{5}$. In this case the patient had hypothyroidism presenting as cutis marmorata with no other characteristic features..

Diagnosis of CMTC is mainly clinical. Histological findings are non-specific and include dilated capillaries in the deeper dermis, swollen endothelial cells and sometimes dilated veins ${ }^{6}$. The risk factors and prognostic factors of CMTC are still unknown. The role of external factors including viral infections has also been suggested as several cases of CMTC occurred in the same geographic area ${ }^{7}$. 
This disease must be differentiated from other reticulated vascular lesions. A rare type of diffuse capillary malformation, Generalised Reticulate Capillary Malformation, can present with a similar clinical picture as CMTC, although it lacks the patchy, linear atrophy and telangiectasia seen in CMTC. Physiological cutis marmorata, a normal response to cold temperatures that occurs during the first few weeks of life, has a much finer, symmetrical pattern over the trunk and extremities, and disappears in warm temperatures. Livedo reticularis and telangiectasia may also be initial signs of neonatal lupus erythematosus. It can be excluded by proper history and maternal blood testing as mothers of infants with neonatal lupus have anti-Ro autoantibodies in $95 \%$ of cases. Naevus flammeus, also easily confused with CMTC, presents with a light coloured, reticular pattern, and does not undergo spontaneous resolution ${ }^{8}$.

Patients with CMTC require long term follow-up for their skin lesions, associated abnormalities and psychomotor development. Associated developmental defects are usually more common in children with widespread generalised CMTC than with more localised or regional CMTC. Overall, the prognosis is very good, as almost all patients show an improvement in the cutaneous lesions during infancy. Rarely, serious complications such as bleeding episodes, gangrenous ulceration and hypovolaemic shock may occur ${ }^{9}$. Few cases of persistent CMTC have been reported, and laser therapy has been tried with variable outcomes ${ }^{10}$. Our patient, who presented with skin lesions with hypothyroidism and was started on thyroid replacement therapy, was followed up in the outpatient department (OPD) and is showing resolution of the skin lesions and is currently euthyoid.

In conclusion, CMTC is a sporadic congenital condition with a typical reticular skin pattern at birth. It can be associated with numerous congenital abnormalities which must be excluded in every case.

\section{References}

1. Van Lohouizen CHJ. Über eine seltene angeborene Hautanomalie (cutis marmorata telangiectatica congenita). Acta DermatoVenereologica (Stockholm) 1922; 3:201-11.

2. Powel ST, Su WP. Cutis marmorata telangiectatica congenita: report of nine cases and review of the literature. Cutis. 1984; 34(3):305-12.
3. Enjolras O, Mulliken JB. Vascular malformations. In: Harper J, Oranje A, Prose $\mathrm{N}$ (eds.) Textbook of Dermatology. Oxford: Blackwell Science; 2000. p. 975-6.

4. Hasegawa Y, Vasuhara M. Phak Pigment type IVa. Archives of Dermatology 1985; 121: 6515. http://dx.doi.org/10.1001/archderm.121.5.651

5. Murphy $\mathrm{CC}$, Khong $\mathrm{CH}$, Ward WJ, Morgan WH. Late-onset paediatric glaucoma associated with cutis marmorata telangiectatica congenita managed with Molteno implant surgery: case report and review of the literature. Journal of the American Association for Paediatric Ophthalmology and Strabismus 2007; 11:519-21.

http://dx.doi.org/10.1016/j.jaapos.2007.03.015

6. Way BH, Herrmann J, Gilbert EF, Johnson SA, Opitz JM. Cutis marmorata telangiectatica congenita. Journal of Cutaneous Pathology 1974; 1:10-25.

http://dx.doi.org/10.1111/j.16000560.1974.tb0 0188.x

7. Happle R. Allelic somatic mutations may explain vascular twin nevi. Human Genetics 1991; 86:321-32.

http://dx.doi.org/10.1007/BF00202421

8. Devillers AC, de Waard-van der Spek FB, Oranje AP. Cutis marmorata telangiectatica congenita: clinical features in 35 cases. Archives of Dermatology 1999; 135:34-8. http://dx.doi.org/10.1001/archderm.135.1.34

9. Hu IJ, Chen MT, Tai HC, Tsao PN, Chou HC, Hsieh WS. Cutis marmorata telangiectatica congenita with gangrenous ulceration and hypovolaemic shock. European Journal of Pediatrics 2005; 164:411-3. http://dx.doi.org/10.1007/s00431-005-1666-3

10. Soo MT, Lo KK, Leung LC. Cutis marmorata telangiectatica congenita. Hong Kong Medical Journal 2007; 13:491-2. 